\title{
3.4 Модель вибору геоінформаційної системи дорожньо-будівельної організації в умовах інтервальної інформації
}

Однією з основних задач геоінформаційних систем є моніторинг стану дорожнього полотна i планування ремонтів. Якщо використовувати геоінформаційні системи для інтеграції різносторонньої інформації про дорожню мережу (види/якість покриття, транспортне навантаження, дати ремонтів), то на іï основі можна побудувати динамічну модель зносу шляхів і автоматизувати планування ремонтів. У базі геоданих також зручно зберігати відомості про дорожні знаки і іншу «придорожню» інформацію, прив'язану до географічних або прямокутних координат [206]. Моніторинг покриття потрібен не тільки автошляхам, але і аеропортам. Тому використання геоінформаційних систем в дорожньо-будівельній організації можуть помітно підвищити ефективність управління будівництвом.

Критерії вибору геоінформаційних систем:

- повнота звітів;

- можливість роботи з різними картами;

- сервісні функції при роботі з картами;

- інтеграція в спеціалізовані облікові програми і системи;

- поділ функцій по галузях діяльності;

- ергономічність інтерфейсу;

- вартість;

- конфіденційність інформації;

- підтримка та оновлення програмного забезпечення;

- навчання та навчальні матеріали.

Програмне забезпечення геоінформаційних систем підтримує той або інший набір функціональних можливостей геоінформаційних систем і включає спеціалізовані програмні засоби, такі як універсальні повнофункціональні геоінформаційні системи, або інструментальні геоінформаційні системи, картографічні візуалізатори, картографічні браузери , засоби настільного картографування, інформаційно-довідкові системи, засоби, що обслуговують 
окремі функціональні групи: конвертування форматів, цифрування, векторизацію, створення й обробку цифрових моделей рельєфу, взаємодія із системами супутникового позиціонування. Комплект поставки програмного забезпечення геоінформаційних систем може включати окремі функціональні модулі, що забезпечують вирішення завдання [207-208].

Спеціалізоване програмне забезпечення геоінформаційних систем, може бути розроблено автономно або на основі адаптації, або доробки існуючих універсальних засобів геоінформаційних систем та призначається для вирішення прикладних завдань. $\mathrm{y}$ комплексі 3 програмним забезпеченням геоінформаційних систем використовуються інші типи програмних засобів пакети статистичного аналізу, системи управління базами даних, системи автоматизованого проєктування, електронні таблиці, засоби цифрової обробки зображень [207-208].

Одною з головних вимог, при проведенні аналізу існуючого програмного інструментарію, є підтримка провідних сучасних технологій, на основі яких може бути побудований якісне, задовольняюче всім світовим стандартам в області розробки програмне забезпечення, а також виконувати всі покладені на нього завдання, програмний продукт [209].

Аналіз [206-209] показав, що вибір програмних засобів проводиться або за прайсами, які торгують даним видом продукції фірм, або за індивідуальним вимогам, які формує замовник.

Актуальність проблеми. Проблема на сьогоднішній день полягає в тому, що існуючі моделі вибору геоінформаційних систем, враховують в основному кількісні чіткі критерії, що робить вибір не завжди ефективним, тому що не дозволяють вирішувати завдання з урахуванням інтервальних оцінок критеріїв вибору. Тому для вирішення даного завдання пропонується використовувати математичний апарат в умовах інтервальної невизначеності [210].

3 огляду на перспективи подальшого розвитку систем підтримки прийняття рішень при їх проектуванні, метою статті є підвищення ефективності будівництва доріг за рахунок розробки моделі вибору геоінформаційної системи 
дорожньо-будівельної організації в умовах інтервальної інформації. Для досягнення поставленої мети необхідно вирішити наступні задачі:

- розробити структурну схему інформаційної технології вибору геоінформаційної системи дорожньо-будівельної організації в умовах інтервальної інформації

- провести аналіз методів прийняття рішень в умовах інтервальної інформації;

- розробити модель вибору геоінформаційної системи дорожньобудівельної організації в умовах інтервальної інформації.

\subsection{1 Структурна схема інформаційної технології вибору} геоінформаційної системи дорожньо-будівельної організації в умовах інтервальної інформації

На рисунку 1 представлена структура інформаційної технології вибору геоінформаційної системи дорожньо-будівельної організації в умовах інтервальної інформації.

Результати кожного з етапів інформаційної технології є вхідними даними для наступних етапів. На кожному з етапів є можливість переходу не тільки на наступний етап, але і на будь-який з попередніх.

Проводиться формалізація всіх етапів проектування, основних елементів інформаційної технології, і розробляються моделі для вирішення кожної задачі.

За допомогою методів багатокритеріальної дискретної оптимізації відбувається отримання результатів, а потім їх оцінка та порівняння з обраною метою. Якщо мета не досягнута, то проводиться корекція раніше прийнятих рішень до тих пір поки мета не буде досягнута.

Розроблена інформаційна технологія дозволяє приймати рішення, щодо вибору геоінформаційної системи і провести перевірку отриманих проектних рішень i, при необхідності, вводити нові елементи в процес. Результати 
порівнюються 3 поставленою метою. Якщо мета досягнута, то переходимо до реалізації рішень, що було сгенеровано.

Даний процес має ітераційний характер, що дозволяє отримати ефективне рішення шляхом аналізу і вибору можливих варіантів побудови рішень. Тому на кожному з етапів є можливість переходу не тільки на наступний етап, але і на будь-який з попередніх.

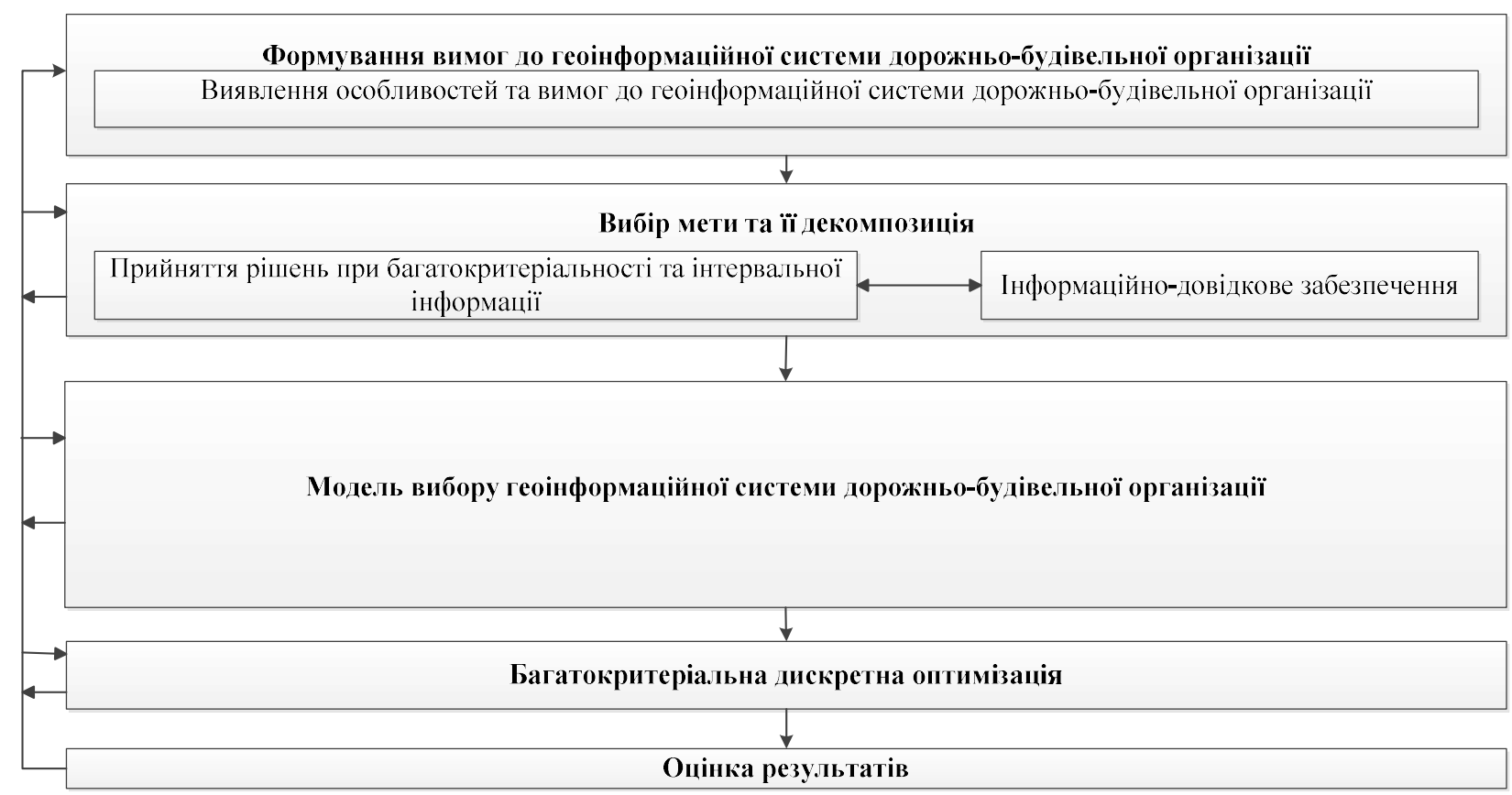

Рисунок 1 - Структура інформаційної технології вибору геоінформаційної системи дорожньо-будівельної організації в умовах інтервальної інформації

Перший етап. Формування вимог до геоінформаційної системи дорожньобудівельної організації

Другий етап. Формування мети та їі декомпозиція, що включає до себе прийняття рішень при багатокритеріальності, інформаційно-довідкове забезпечення.

Третій етап Модель вибору геоінформаційної системи дорожньобудівельної організації.

Четвертий етап. Багатокритеріальна дискретна оптимізація.

П’ятий етап. Оцінка результатів. 


\subsection{2 Методи прийняття рішень в умовах інтервальної інформації}

У більшості задач багатокритеріальної оптимізації, значення окремих критеріїв задаються в інтервальному вигляді і статистична інформація про характер розподілу значень усередині інтервалу невідома. Експерт в такому випадку може призначити функцію приналежності всередині інтервалу. Тоді значення часткового критерію буде представлено у вигляді нечіткого числа 3 функцією належності, при цьому, то значення функції приналежності, при якому вона дорівнює одиниці не обов'язково буде знаходитися на середині інтервалу [209].

Особливість прийняття рішень в умовах інтервальної невизначеності полягає в тому, що особа, що приймає рішення має інформацію про межі можливих значень змінних, але завжди апріорна інформація про перевагу, характер розподілу можливих значень змінних всередині інтервалу повністю відсутня. При цьому передбачається, що зовнішнє середовище поводиться пасивно, тобто його стан не пов'язано з рішеннями, які реалізує особа, що приймає рішення [210 - 214].

Метою є вибір такої альтернативи, що була б краще за деяким критерієм. При інтервальній невизначеності, повністю відсутня об'єктивна інформація, на основі якої можна було б визначити метрику для відносної оцінки якості допустимих рішень. Таким чином, розглянута задача прийняття рішень $\epsilon$ некоректною (не має однозначної відповіді) і потребує регуляризації, заснованої на залученні зовнішнього, по відношенню до вихідної постановці завдання, інформації. Джерелом такої інформації в ситуації, що розглядається є особа, що приймає рішення, яка на основі свого досвіду, знань, інтуїції висуває деякі гіпотези, в рамках яких формується правило (критерій) вибору ефективного рішення [211]. Розглянемо критерії прийняття проектних рішень для оптимістичної та песимістичної ситуацї. 
У випадках песимістичної оцінки застосовуємо максимінний критерій Вальда. Цей критерій $є$ найбільш обережним, оскільки він грунтується на виборі найкращого 3 найгірших можливостей. Тому його іноді називають критерієм крайнього песимізму [211]. згідно з критерієм

$$
x^{0}=\underset{x \in X}{\arg \max _{1 \leq j \leq m}} \frac{1}{m} \sum_{j=1}^{m} f\left(x_{i}, s_{j}\right),
$$

де $\mathrm{f}\left(\mathrm{x}_{\mathrm{i}}, \mathrm{s}_{\mathrm{j}}\right)$ - оцінка проектного рішення;

х

$\mathrm{S}_{\mathrm{j}}$ - стан середовища функціонування.

Правило вибору рішення відповідно до критерію Вальда можна інтерпретувати в такий спосіб. Матриця виграшів доповнюється стовпцем, кожен елемент якого являє собою мінімальне значення виграшу для відповідної стратегії особи, що приймає рішення [211]:

$$
\mathrm{W}_{\mathrm{i}}\left(\mathrm{x}_{\mathrm{i}}\right)=\min _{1 \leq \mathrm{j} \leq \mathrm{m}} \mathrm{f}\left(\mathrm{x}_{\mathrm{i}}, \mathrm{s}_{\mathrm{j}}\right) .
$$

Оптимальною за даним критерієм вважається та стратегія особи, що приймає рішення при виборі, якої мінімальне значення виграшу максимально:

$$
\mathrm{x}^{0}=\arg \max _{1 \leq \mathrm{i} \leq \mathrm{n}} \mathrm{W}_{\mathrm{i}}\left(\mathrm{x}_{\mathrm{i}}\right)
$$

Обрана таким чином стратегія повністю виключає ризик. Це означає, що приймає рішення не може отримати найгірший результат, ніж той, на який він орієнтується, цей результат йому гарантований [211].

Слід зазначити, що вкрай оптимістичне рішення дає вибір 


$$
x^{0}=\arg \max _{x \in X} \max _{1 \leq j \leq m} f\left(x_{i}, s_{j}\right) .
$$

У практиці прийняття рішень особа, що приймає рішення керується не тільки критеріями, пов'язаними 3 крайнім песимізмом або урахуванням максимального ризику. Намагаючись зайняти найбільш виважену позицію, особа, що приймає рішення може ввести оціночний коефіцієнт, званий коефіцієнтом песимізму, Який вибирається в інтервалі $[205,206]$ і відображає проміжну ситуацію між точками зору крайнього оптимізму та крайнього песимізму. Цей коефіцієнт визначається на основі оцінки обстановки, що склалася і особистого досвіду прийняття рішення в подібних ситуаціях. Критерій Гурвіца виражається співвідношенням [211]:

$$
x^{0}=\arg \max _{1 \leq i \leq n}\left[a \cdot \min _{1 \leq j \leq m} f\left(x_{i}, s_{j}\right)+(1-a) \cdot \max _{1 \leq j \leq m} f\left(x_{i}, s_{j}\right)\right] .
$$

При визначенні оптимальної стратегії за критерієм Гурвіца матриця виграшів доповнюється стовпцем, елементи якого розраховуються за формулою [211]:

$$
H_{i}\left(x_{i}\right)=a \cdot \min _{1 \leq j \leq m} f\left(x_{i}, s_{j}\right)+(1-a) \cdot \max _{1 \leq j \leq m} f\left(x_{i}, s_{j}\right) .
$$

Оптимальною за даним критерієм вважається стратегія, в якій значення максимально:

$$
\mathrm{x}^{0}=\arg \max _{1 \leq \mathrm{i} \leq \mathrm{n}} \mathrm{H}_{\mathrm{i}}\left(\mathrm{x}_{\mathrm{i}}\right)
$$




\subsection{3 Модель вибору геоінформаційної системи дорожньо-будівельної організації}

Введемо змінну $X_{\sigma c v}=\{0 ; 1\}$, де $X_{\sigma c v}=1-$ якщо обрано геоінформаційну систему $c$-го типу, $v$-го виду для виконання $\sigma$-ї функції, $X_{\sigma c v}=0-$ в зворотньому випадку; $Y_{\sigma v}=\{0 ; 1\}$, де $Y_{\sigma v}=1$ - якщо $\sigma$-у функцію може забезпечити $c v$-а геоінформаційна система, $Y_{\sigma v}=0$ - в зворотньому випадку.

Часткові критерії оптимізації:

- максимальна швидкість виконання $\sigma$-ї функції геоінформаційними системами

$$
V_{P}=\min \sum_{\sigma=1}^{\sigma^{\prime}} \sum_{c=1}^{c^{s}} \sum_{v=1}^{v^{c}} \sum_{x=1}^{x^{\prime}} V_{\sigma v} Y_{\sigma v} X_{\sigma c v}
$$

де $S_{c v}$-інтервальна оцінка виконання $\sigma$-ї функції геоінформаційними системами $c$-го типа $v$-го виду;

- мінімальні вимоги геоінформаційних систем до технічних характеристик технічних засобів

$$
R_{P}=\min \sum_{\sigma=1}^{\sigma^{\prime}} \sum_{c=1}^{c^{s}} \sum_{v=1}^{v^{c}} \sum_{x=1}^{x^{\prime}} R_{\sigma v x} Y_{\sigma v} X_{\sigma c v}
$$

де $R_{c v} \xi$-інтервальна оцінка $\xi$-ї вимоги геоінформаційної системами $c$-го типу, $v$-го виду до технічних характеристик ТЗ; $\xi^{\prime}$ - кількість вимог;

- мінімальна вартість геоінформаційних систем

$$
C_{P}=\min \sum_{s=1}^{s^{\prime}} \sum_{c=1}^{c^{s}} \sum_{v=1}^{v^{c}} C_{c v} Y_{s c v} X_{s c v}
$$


де $C_{c v}$ - інтервальна оцінка вартості геоінформаційних систем $c$-го типу $v$-го виду.

Область допустимих рішень визначається обмеженнями:

- виконання всіх функцій повинно бути забезпечене геоінформаційними системами

$$
\sum_{s=1}^{s^{\prime}} \sum_{c=1}^{c^{s}} \sum_{v=1}^{v^{c}} Y_{s c v} X_{s c v}=s^{\prime}
$$

- мінімальна швидкість виконання $\sigma$-ї функції геоінформаційними системами повинна бути не нижче $V_{c \mathrm{~min}}^{\text {in }}$

$$
\sum_{s=1}^{s^{\prime}} V_{c v} Y_{s c v} X_{s c v} \geq V_{c v}^{m i n} ; \quad c=\overline{1, c^{\sigma}} ; \quad v=\overline{1, v^{c}}
$$

- вимоги $c v$-го геоінформаційної системи до $\xi$-ї технічної характеристики технічного засобу при виконанні $\sigma$-ї функції повинні не перевищувати заданих $R_{\sigma \xi}^{0}$

$$
R_{c v \xi} Y_{\sigma c v} X_{\sigma c v} \leq R_{\sigma \xi}^{0} ; \quad c=\overline{1, c^{\sigma}} ; \quad v=\overline{1, v^{c}} ; \quad \sigma=\overline{1, \sigma^{\prime}} ; \quad \xi=\overline{1, \xi^{\prime}}
$$

- вартість геоінформаційних систем повинна бути не більше заданої $C^{0}$

$$
\sum_{\sigma=1}^{\sigma^{\prime}} \sum_{c=1}^{c^{\sigma}} \sum_{v=1}^{v^{c}} C_{\sigma c v} Y_{\sigma c v} X_{\sigma c v} \leq C^{0}
$$


Моделі (8) - (14) відносяться до задач багатокритеріального дискретного програмування з булевими змінними, що вирішуються: методом спрямованого перебору при прийнятті рішень у задачах невеликої розмірності; методом випадкового пошуку - в задачах великої розмірності.

В результаті виконаного дослідження була розроблена модель вибору геоінформаційної системи дорожньо-будівельної організації в умовах інтервальної інформації, яка дозволяє підвищити ефективність управління будівництвом доріг.

Розроблена інформаційна технологія та модель орієнтовані для впровадження в будівельних, дорожніх, логістичних і інших організаціях. 